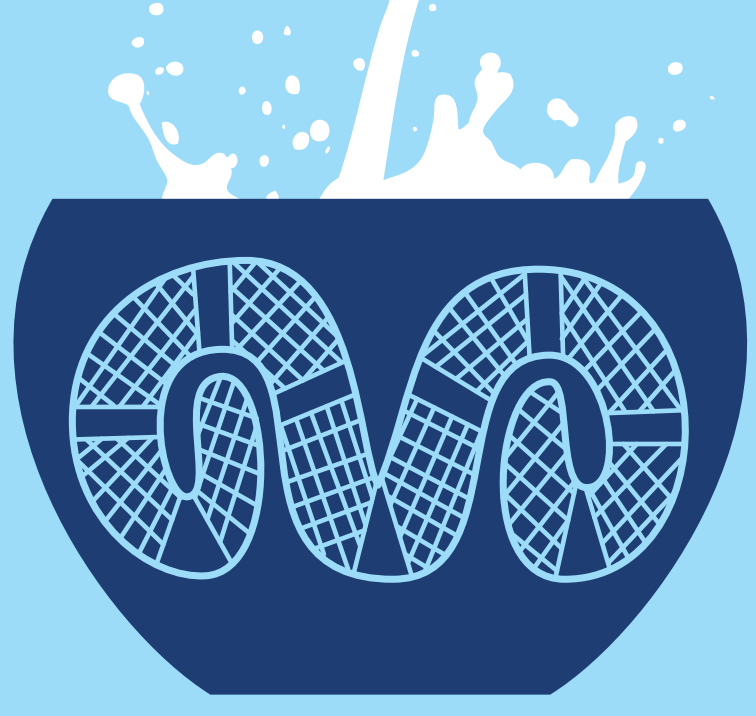

\title{
The milk revolution
}

\author{
When a single genetic mutation first let ancient Europeans \\ drink milk, it set the stage for a continental upheaval.
}

\section{BY ANDREW CURRY}

I n the 1970s, archaeologist Peter Bogucki was excavating a Stone Age site in the ferLile plains of central Poland when he came across an assortment of odd artefacts. The people who had lived there around 7,000 years ago were among central Europe's first farmers, and they had left behind fragments of pottery dotted with tiny holes. It looked as though the coarse red clay had been baked while pierced with pieces of straw.

Looking back through the archaeological literature, Bogucki found other examples of ancient perforated pottery. "They were so unusual - people would almost always include them in publications," says Bogucki, now at Princeton University in New Jersey. He had seen something similar at a friend's house that was used for straining cheese, so he speculated that the pottery might be connected with cheesemaking. But he had no way to test his idea.

The mystery potsherds sat in storage until 2011, when Mélanie Roffet-Salque pulled them out and analysed fatty residues preserved in the clay. Roffet-Salque, a geochemist at the University of Bristol, UK, found signatures of abundant milk fats - evidence that the early dence of cheese-making in the world ${ }^{1}$.
D NATURE.COM To hear Mark Thomas discuss the milk revolution, visit: go.nature.com/aleyte

farmers had used the pottery as sieves to separate fatty milk solids from liquid whey. That makes the Polish relics the oldest known evi-

Roffet-Salque's sleuthing is part of a wave of discoveries about the history of milk in Europe. Many of them have come from a $€ 3$.3-million (US\$4.4-million) project that started in 2009 and has involved archaeologists, chemists and geneticists. The findings from this group illuminate the profound ways that dairy products have shaped human settlement on the continent.

During the most recent ice age, milk was essentially a toxin to adults because - unlike children - they could not produce the lactase enzyme required to break down lactose, the main sugar in milk. But as farming started to replace hunting and gathering in the Middle East around 11,000 years ago, cattle herders learned how to reduce lactose in dairy products to tolerable levels by fermenting milk to make cheese or yogurt. Several thousand years later, a genetic mutation spread through Europe that gave people the ability to produce lactase — and drink milk - throughout their lives. That adaptation opened up a rich new source of nutrition that could have sustained communities when harvests failed.

This two-step milk revolution may have been a prime factor in allowing bands of farmers and herders from the south to sweep through Europe and displace the hunter-gatherer cultures that had lived there for millennia. "They spread really rapidly into northern Europe from an archaeological point of view," says Mark Thomas, a population geneticist at University College London. That wave of emigration left an enduring imprint on Europe, where, unlike in many regions of the world, most people can now tolerate milk. "It could be that a large proportion of Europeans are descended from the first lactase-persistent dairy farmers in Europe," says Thomas.

\section{STRONG STOMACHS}

Young children almost universally produce lactase and can digest the lactose in their mother's milk. But as they mature, most switch off the lactase gene. Only $35 \%$ of the human 
population can digest lactose beyond the age of about seven or eight (ref. 2). "If you're lactose intolerant and you drink half a pint of milk, you're going to be really ill. Explosive diarrhoea - dysentery essentially," says Oliver Craig, an archaeologist at the University of York, UK. "I'm not saying it's lethal, but it's quite unpleasant."

Most people who retain the ability to digest milk can trace their ancestry to Europe, where the trait seems to be linked to a single nucleotide in which the DNA base cytosine changed to thymine in a genomic region not far from the lactase gene. There are other pockets of lactase persistence in West Africa (see Nature $\rightarrow$ 444, 994-996; 2006), the Middle East and 岸 south Asia that seem to be linked to separate mutations ${ }^{3}$ (see 'Lactase hotspots').

The single-nucleotide switch in Europe happened relatively recently. Thomas and his colleagues estimated the timing by looking at genetic variations in modern populations and running computer simulations of how the related genetic mutation might have spread through ancient populations ${ }^{4}$. They proposed

$\frac{1}{2}$ that the trait of lactase persistence, dubbed the LP allele, emerged about 7,500 years ago in the broad, fertile plains of Hungary.

\section{POWERFUL GENE}

Once the LP allele appeared, it offered a major selective advantage. In a 2004 study $^{5}$, researchers estimated that people with the mutation would have produced up to $19 \%$ more fertile offspring than those who lacked it. The researchers called that degree of selection "among the strongest yet seen for any gene in the genome".

Compounded over several hundred generations, that advantage could help a population to take over a continent. But only if "the population has a supply of fresh milk and is dairying", says Thomas. "It's gene-culture coevolution. They feed off of each other."

To investigate the history of that interaction, Thomas teamed up with Joachim Burger, a palaeogeneticist at the Johannes Gutenberg University of Mainz in Germany, and Matthew Collins, a bioarchaeologist at the University of York. They organized a multidisciplinary project called LeCHE (Lactase Persistence in the early Cultural History of Europe), which brought together a dozen early-career researchers from around Europe.

By studying human molecular biology and the archaeology and chemistry of ancient pottery, LeCHE participants also hoped to address a key issue about the origins of modern Europeans. "It's been an enduring question in archaeology - whether we're descended from Middle Eastern farmers or indigenous hunter-gatherers," says Thomas. The argument boils down to evolution versus replacement. Did native populations of hunter-gatherers in Europe take up farming and herding? Or was there an influx of agricultural colonists who outcompeted the locals, thanks to a combination of genes and technology?
One strand of evidence came from studies of animal bones found at archaeological sites. If cattle are raised primarily for dairying, calves are generally slaughtered before their first birthday so that their mothers can be milked. But cattle raised mainly for meat are killed later, when they have reached their full size. (The pattern, if not the ages, is similar for sheep and goats, which were part of the dairying revolution.)

On the basis of studies of growth patterns in bones, LeCHE participant Jean-Denis Vigne, an archaeozoologist at the French National Museum of Natural History in Paris, suggests that dairying in the Middle East may go all the way back to when humans first started domesticating animals there, about 10,500 years ago ${ }^{6}$. That would place it just after the Middle Eastern Neolithic transition - when an economy based on hunter-gathering gave way to one devoted to agriculture. Dairying, says Roz Gillis, also an archaeozoologist at the Paris museum, "may have been one of the reasons why human populations began trapping and keeping ruminants such as cattle, sheep and goats". (See 'Dairy diaspora')

Dairying then expanded in concert with

\section{DAIRY DIASPORA}

Dairying practices spread from the Middle East to Europe as part of the Neolithic transition from hunting and gathering to agriculture.

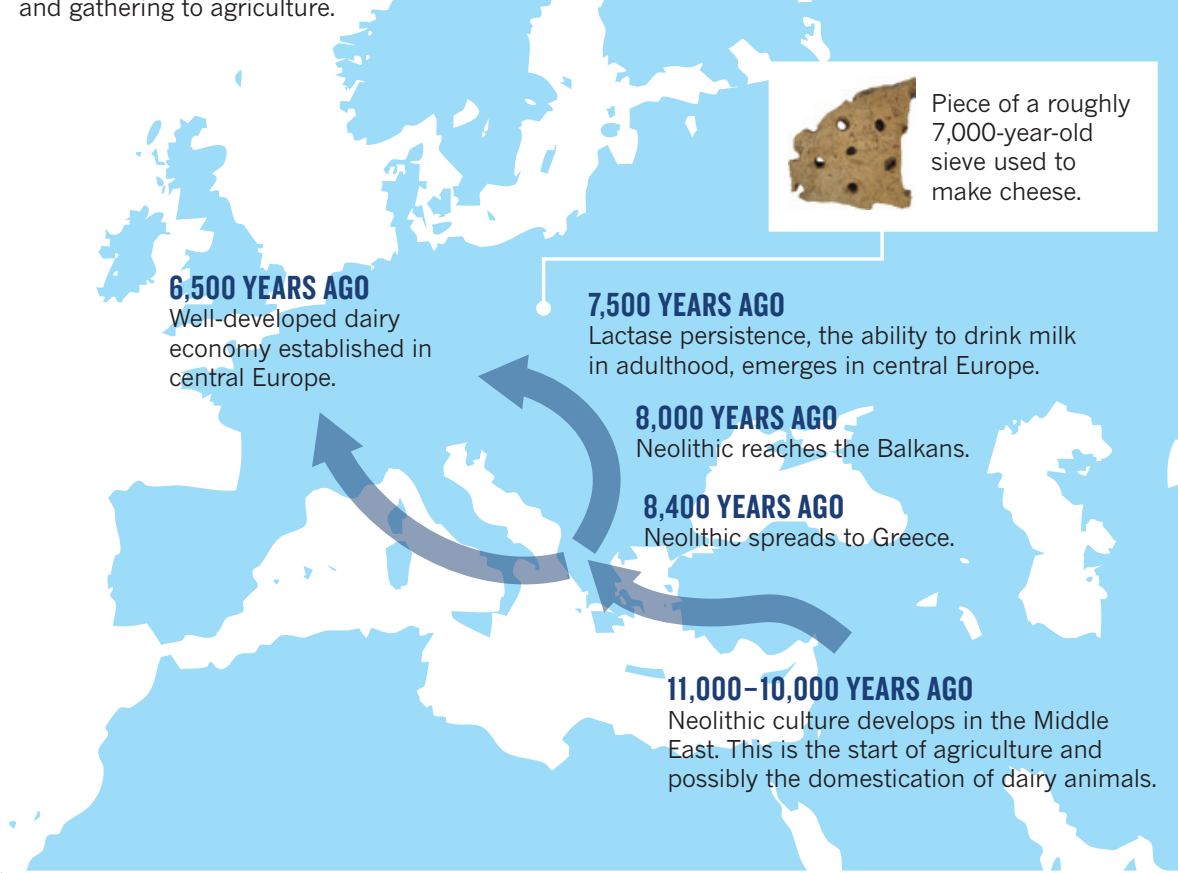

\section{LACTASE HOTSPOTS}

Only one-third of people produce the lactase enzyme

during adulthood, which enables them to drink milk.

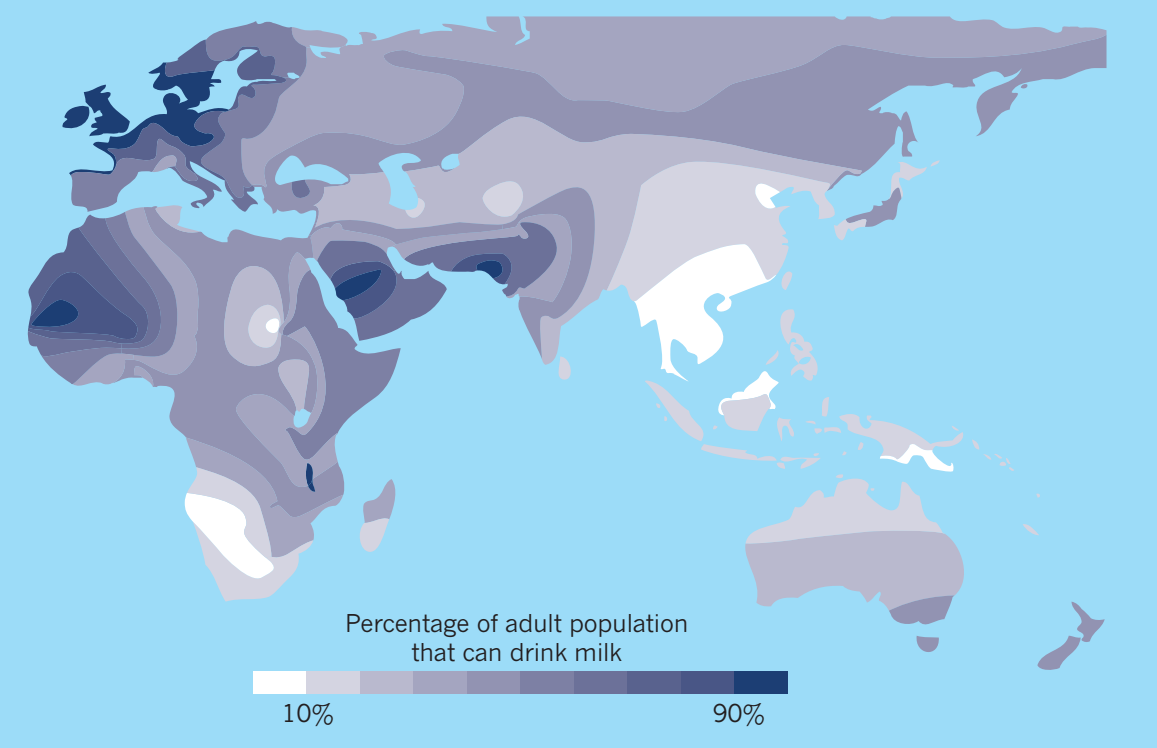


the Neolithic transition, says Gillis, who has looked at bone growth at 150 sites in Europe and Anatolia (modern Turkey). As agriculture spread from Anatolia to northern Europe over roughly two millennia, dairying followed a similar pattern.

On their own, the growth patterns do not say whether the Neolithic transition in Europe happened through evolution or replacement, but cattle bones offer important clues. In a precursor study ${ }^{7}$, Burger and several other LeCHE participants found that domesticated cattle at Neolithic sites in Europe were most closely related to cows from the Middle East, rather than indigenous wild aurochs. This is a strong indication that incoming herders brought their cattle with them, rather than domesticating locally, says Burger.

A similar story is emerging from studies of ancient human DNA recovered at a few sites in central Europe, which suggest that Neolithic farmers were not descended from the huntergatherers who lived there before ${ }^{8}$.

Taken together, the data help to resolve the origins of the first European farmers. "For a long time, the mainstream of continental European archaeology said Mesolithic huntergatherers developed into Neolithic farmers," says Burger. "We basically showed they were completely different."

\section{MILK OR MEAT}

Given that dairying in the Middle East started thousands of years before the LP allele emerged in Europe, ancient herders must have found ways to reduce lactose concentrations in milk. It seems likely that they did so by making cheese or yogurt. (Fermented cheeses such as feta and cheddar have a small fraction of the lactose found in fresh milk; aged hard cheeses similar to Parmesan have hardly any.)

To test that theory, LeCHE researchers ran chemical tests on ancient pottery. The coarse, porous clay contains enough residues for chemists to distinguish what type of fat was absorbed during the cooking process: whether it was from meat or milk, and from ruminants such as cows, sheep and goats or from other animals. "That gave us a way into saying what types of things were being cooked," says Richard Evershed, a chemist at the University of Bristol.

Evershed and his LeCHE collaborators found milk fat on pottery in the Middle Eastern Fertile Crescent going back at least 8,500 years ${ }^{9}$, and Roffet-Salque's work on the Polish pottery ${ }^{1}$ offers clear evidence that herders in Europe were producing cheese to supplement their diets between 6,800 and 7,400 years ago. By then, dairy had become a component of the Neolithic diet, but it was not yet a dominant part of the economy.

That next step happened slowly, and it seems to have required the spread of lactase persistence. The LP allele did not become common in the population until some time after it first emerged: Burger has looked for the mutation in samples of ancient human DNA and has found it only as far back as 6,500 years ago in northern Germany.

Models created by LeCHE participant Pascale Gerbault, a population geneticist at University College London, explain how the trait might have spread. As Middle Eastern Neolithic cultures moved into Europe, their farming and herding technologies helped them to out-compete the local hunter-gatherers. And as the southerners pushed north, says Gerbault, the LP allele 'surfed' the wave of migration.

Lactase persistence had a harder time

naturally only when exposed to the sun, which makes it difficult for northerners to make enough during winter months. But lactase persistence also took root in sunny Spain, casting vitamin D's role into doubt.

The LeCHE project may offer a model for how archaeological questions can be answered using a variety of disciplines and tools. "They have got a lot of different tentacles - archaeology, palaeoanthropology, ancient DNA and modern DNA, chemical analysis - all focused on one single question," says Ian Barnes, a palaeogeneticist at Royal Holloway, University of London, who is not involved in the project. "There are lots of other dietary changes which could be studied in this way."

The approach could, for example, help to tease apart the origins of amylase, an enzyme that helps to break down starch. Researchers have suggested that the development of the enzyme may have

becoming established in parts of southern Europe, because Neolithic farmers had settled there before the mutation appeared. But as the agricultural society expanded northwards and westwards into new territory, the advantage provided by lactase persistence had a big impact. "As the population grows quickly at the edge of the wave, the allele can increase in frequency," says Gerbault.

The remnants of that pattern are still visible today. In southern Europe, lactase persistence is relatively rare - less than $40 \%$ in Greece and Turkey. In Britain and Scandinavia, by contrast, more than $90 \%$ of adults can digest milk.

\section{CATTLE CONQUEST}

By the late Neolithic and early Bronze Age, around 5,000 years ago, the LP allele was prevalent across most of northern and central Europe, and cattle herding had become a dominant part of the culture. "They discover this way of life, and once they can really get the nutritional benefits they increase or intensify herding as well," says Burger. Cattle bones represent more than two-thirds of the animal bones in many late Neolithic and early Bronze Age archaeological sites in central and northern Europe.

The LeCHE researchers are still puzzling out exactly why the ability to consume milk offered such an advantage in these regions. Thomas suggests that, as people moved north, milk would have been a hedge against famine. Dairy products - which could be stored for longer in colder climes - provided rich sources of calories that were independent of growing seasons or bad harvests.

Others think that milk may have helped, particularly in the north, because of its relatively high concentration of vitamin $\mathrm{D}$, a nutrient that can help to ward off diseases such as rickets. Humans synthesize vitamin D followed - or made possible - the increasing appetite for grain that accompanied the growth of agriculture. Scientists also want to trace the evolution of alcohol dehydrogenase, which is crucial to the breakdown of alcohol and could reveal the origins of humanity's thirst for drink.

Some of the LeCHE participants are now probing further back in time, as part of a project named BEAN (Bridging the European and Anatolian Neolithic), which is looking at how the first farmers and herders made their way into Europe. Burger, Thomas and their BEAN collaborators will be in Turkey this summer, tracing the origins of the Neolithic using computer models and ancient-DNA analysis in the hope of better understanding who the early farmers were, and when they arrived in Europe.

Along the way, they will encounter beyaz peynir, a salty sheep's-milk cheese eaten with nearly every Turkish breakfast. It is probably much like the cheese that Neolithic farmers in the region would have eaten some 8,000 years ago - long before the march of lactase persistence allowed people to drink fresh milk.

Andrew Curry is a freelance writer in Berlin.

1. Salque, M. et al. Nature $493,522-525$ (2013).

2. Leonardi, M., Gerbault, P., Thomas, M. G. \&

Burger, J. Int. Dairy J. 22, 88-97 (2012).

3. Gerbault, P. et al. Phil. Trans. R. Soc. B 366, 863-877 (2011).

4. Itan, Y., Powell, A., Beaumont, M. A., Burger, J. \& Thomas, M. G. PLoS Comp. Biol. 5, e1000491 (2009).

5. Bersaglieri, T. et al. Am. J. Hum. Genet. 74, 1111-1120 (2004).

6. Vigne, J.-D. in The Neolithic Demographic Transition and its Consequences (eds Bocquet-Appel, J.-P. \& Bar-Yosef, 0.) 179-205 (Springer, 2008).

7. Edwards, C. J. et al. Proc. R. Soc. B 274, 1377-1385 (2007).

8. Bramanti, B. et al. Science 326, 137-140 (2009)

9. Evershed, R. P. et al. Nature 455, 528-531 (2008) 